\begin{tabular}{|l|l|l||}
\hline \multicolumn{2}{|c|}{ PublisherInfo } \\
\hline \hline PublisherName & $:$ & BioMed Central \\
\hline \hline PublisherLocation & $:$ & London \\
\hline \hline PublisherImprintName & $:$ & BioMed Central \\
\hline \hline
\end{tabular}

\title{
Earlier than immediate-early
}

\begin{tabular}{|l|l|l||}
\hline \multicolumn{2}{|c|}{ ArticleInfo } \\
\hline \hline ArticleID & $:$ & 3718 \\
\hline \hline ArticleDOI & $:$ & $10.1186 /$ gb-spotlight-20000706-01 \\
\hline \hline ArticleCitationID & $:$ & spotlight-20000706-01 \\
\hline \hline ArticleSequenceNumber & $:$ & 155 \\
\hline \hline ArticleCategory & $:$ & Research news \\
\hline ArticleFirstPage & $:$ & 1 \\
\hline \hline ArticleLastPage & $:$ & 2 \\
\hline \hline & $:$ & RegistrationDate : 2000-07-06 \\
ArticleHistory & $:$ & OnlineDate \\
\hline \hline ArticleCopyright & $:$ & BioMed Central Ltd2000-07-06 \\
\hline \hline ArticleGrants & $:$ & \\
\hline \hline ArticleContext & $:$ & 130591111 \\
\hline \hline
\end{tabular}




\section{William Wells}

Email: wells@biotext.com

The definition of a virus as a DNA or RNA virus, based on its genetic material, is now on shaky ground thanks to the findings of Bresnahan and Shenk in the 30 June Science. Using a gene array, they find that particles of human cytomegalovirus (HCMV), a large DNA virus, contain four different mRNAs (Science 2000, 288:2373-2376). The mRNAs are derived from one immediate-early gene, two early genes and one late gene, but translation from at least one of the packaged mRNAs peaks before there is detectable translation from the most abundant immediate-early mRNA. The functions of the four mRNAs is unknown, but the protein product from one of the mRNAs is directed to the Golgi network. This co-translational sorting would not occur if the mRNA species was replaced in the virion by a protein.

\section{References}

1. Science magazine, [http://www.sciencemag.org/] 